\title{
Chernozem (czarnoziem) - soil of the year 2019 in Poland. Origin, classification and use of chernozems in Poland
}

\begin{abstract}
The Soil Science Society of Poland has elected chernozem to be the Soil of the Year 2019. Although chernozems cover less than $2 \%$ of Poland, they have high importance for agriculture due to their productivity and play a specific scientific role for understanding of soil development and functioning in an environment. Chernozems are also crucial for the reconstruction of Neolithic agriculture development and human impacts on soil and landscape. This introductory paper presents (a) a specific definition of chernozem in Poland, connected with a separate distinction of black earths and colluvial chernozemic soils; (b) a review of the present and former classification schemes for chernozems in Poland and their correlation with international soil classification systems (WRB and Soil Taxonomy); (c) the spatial distribution of chernozems in Poland, their agricultural evaluation and threats for chernozems' quality and future existence related to intense land use.
\end{abstract}

Keywords: Chernozems, Phaeozems, Mollisols, soil origin, soil classification, soil functions

\section{INTRODCTION}

Chernozem has been considered in many countries a synonym for the most fertile and productive arable soil, suitable for cultivation of demanding crops, such as sugar beet, barley, wheat and corn. Thus, chernozems $^{1}$ have been the subject of significant public concern and interest of pedologists and agronomists. In this context, it has become clear that Chernozems/ Mollisols are local icons - 'state soils' - such as in Nebraska (USA), Ukraine and the Belgorod region (Russia), and have been appointed a 'soil of the year' by national pedological societies, as in Germany and Estonia (Altermann et al. 2005; Kõlli and Tamm 2015; Pozniak and Havrysh 2019). Although rendzina was elected (by the Commission of Soil Genesis, Classification and Cartography of the Soil Science Society of Poland (SSSP)) the first 'soil of the year' toinaugurate the programme in Poland in 2018, due to its specific historical importance for the Polish soil science (Kabała 2018), chernozem had already been appointed the second 'soil of the year' to celebrate it in 2019. This decision was also connected with the organisation of the SSSP congress in Lu-

\footnotetext{
${ }^{1}$ The common names of soil units (e.g., chernozems, black soils/earths and rendzina) are written in lowercase unless they refer to Reference Soil Groups of WRB or soil Taxonomy, in which case they are written in capital letters.
}

blin, the capital of the region known for its fertile chernozems (Borowiec 1965, 1976).

\section{CONCEPTS OF CHERNOZEM FORMATION}

Numerous early attempts were undertaken to explain the origin of soils featured by thick, black, humus-rich topsoil horizon, including their marine or alluvial formation (Labaz et al. 2018; Vysloužilová et al. 2016). The most widely accepted until now is a theory of Dokuchaev (1883), who defined chernozem as an autogenic natural body, developed under interconnected influences of various environmental factors, including calcareous but permeable parent rock, climate, vegetation, fauna and relief. Dokuchaev confirmed, what seems today absolutely obvious, that the organic matter of chernozems originates in terrestrial plants, those species' composition being closely related to climate. The organic matter, primarily the underground remains of roots, does not decompose rapidly because of seasonal dryness and stabilization by calcium in a carbonate-rich soil substratum, mostly the loess. Moreover, the organic matter and bulk soil is vertically and horizontally translocated by burrowing animals (both earthworms and rodents), which are particularly common in a virgin continental steppe. Zooturbation results in a thickening of the humus-rich topsoil layer and an improvement of the 
soil mass aggregation (Ponomarenko and Ponomarenko 2019). Because the climate-related continental steppe vegetation is zonal, the chernozem is also considered zonal soil. Dokuchaev and his followers have distinguished the common (typical) chernozems of the central, tall-grass steppe belt, the southern chernozems of the short-grass dry steppe and also the 'degraded' chernozems of the moister forest-steppe zone located north of the central (continental) steppe zone (Strzemski 1971). The steppe origin of the common (typical) and southern chernozems generally has not been questioned because the conditions favourable for chernozem formation still exist in many sites of the world, and active chernozem development can be presently observed (Alexandrovskiy 2007; Khitrov et al. 2019; Liu et al. 2012). In contrast, the nature of 'degraded' chernozems has been continuously discussed until now (Eckmeier et al. 2007; Vysloužilová et al. 2016).

The first concept, probably the most common, assumes that the chernozems in the northern and western peripheries and isolated "islands" outside the central steppe belt have developed under a cold or temperate steppe vegetation and then have been transformed (degraded) by forest vegetation that succeeded onto former steppe areas (e.g. in Central Europe) after climate warming and moistening (Czerny and Sachsse 1965; Miklaszewski 1930). Following this concept, chernozems in northern Central Europe and northern Russia are relics, developed in the late Pleistocene or early Holocene, before the Atlantic climate optimum (Borowiec 1962; Hajdukiewicz 2010; KołodyńskaGawrysiak et al. 2017). Alternatively, the formation of chernozems under an open-canopy forest-steppe or meadow-forest vegetation was considered without specification of the time of development (Borowiec 1967; Strzemski 1961; Vysloužilováet al. 2014). Following this concept, chernozems developed under a less continental (moister) climate, and transitional or variable (in space and time) vegetation cannot be considered 'degraded'. Their chernozemic features are differently expressed, respectively to conditions of their formation (Borowiec 1968). As a consequence of temporary coverage with close-canopy forest vegetation, these chernozems may be featured by clay and humus eluviation/illuviation (Kowaliński et al. 1987; Licznar 1976; Miedema et al. 1999). These two general concepts, considered contradictory, in fact complement each other and are accompanied by a few others. The concept of the relatively young age of chernozems in Central Europe (i.e. their formation in or since the Neolithic period) (Maruszczak 1998; Vysloužilová et al. 2016) has become increasingly popular. However, some researchers assume that the large scale of forest clearance by Neolithic people has allowed reconstruction of steppe or a domination of steppe-forest/meadowforest vegetation that created conditions supporting the formation or reconstruction of chernozems in Central Europe (Chmielewski et al. 2014; Ehwald et al. 1999; Jacomet et al. 2016; Pokorný et al. 2015; Suchodoletz et al. 2017). In contrast, other researchers assume that the large-scale forest burning by Neolithic people was a single factor that enabled chernozem formation by the production of large amounts of fine particles of black carbon (charcoal), which has strongly coloured the topsoil after mixing (Eckmeier et al. 2007). Recently, a polygenetic formation of 'extrazonal' chernozems in Central Europe has been postulated, bringing together many of the previous separate concepts (i.e. it assumes initial chernozem formation in the late Pleistocene/early Holocene under cold-steppe vegetation and their 'rejuvenation' or second phase of development in/ since the Neolithic period under human-induced forest-steppe (-meadow) vegetation developed after large-scale forest clearance (Kabała et al. 2019b; Łabaz et al. 2018). However, it is highly probable there is no one scenario of chernozem development and transformation in all Central Europe, but rather various scenarios may be true in particular sites, which differ in parent materials, relief, moisture regime, vegetation history, length and intensity of human impacts etc.

An important issue influencing the discussion on chernozem origin is the moist water regime in many chernozemic soils connected with the development of abundant redoximorphic features, typical for soils developed under humid rather than continental climates. This issue led some, even modern scientists, to the conclusions on the hydrogenic origin of chernozems (Turski 1985), or, at least, to the questioning of their steppe origin (Eckmeier et al. 2007).

\section{DEVELOPMENT OF THE DEFINITION AND CLASSIFICATION OF CHERNOZEMS IN POLAND}

The East-Slavic (Ukrainian - Russian) word 'czarnoziem' has been occasionally used in legal Polish documents referring to the evaluation of arable lands at least since the mid-19 $9^{\text {th }}$ century (Strzemski 1980). The modern understanding of chernozems was introduced to the Polish professional literature by Miklaszewski (1906) who has good knowledge about the Dokuchaev concepts. 'Właściwy czarnoziem' (proper or common chernozem) has been defined here and in the further works of this author (Miklaszewski 1930) as a mineral soil developed from loess (at least the 
humus horizon), having thick humus horizon (40-140 $\mathrm{cm}$, mean $70 \mathrm{~cm}$ ) and carbonates in the profile, sometimes even in the topsoil layer. Chernozem contains 'sweet' humus derived from a non-bog vegetation. All 'common chernozems' are originally steppe soils, featured by abundant channels of burrowing animals, presently inactive, filled with humic soil mass. Following the Russian authors, Miklaszewski (1930) considered the Polish chernozems to be 'degraded' because they contain no more than 2 to $3 \%$ of humus (on average) in topsoil layers that is 2 to 4 times less than the Russian chernozems have (Khitrov et al. 2013). The agricultural suitability of chernozems depends on their parent material. Chernozems developed from deep loess have the best physicochemical, water and air properties, and therefore the highest productivity, even if 'degraded' by lower humus content (Miklaszewski 1930). Chernozems developed from loess in topsoil and underlain by cracked limestone or sand in the subsoil have potentially good fertility, but suffer from seasonal dryness, whereas chernozems developed from loess in topsoil and underlain by heavy loam or clay, impermeable to water, are too moist, an issue which may eliminate some crops (Miklaszewski 1930). Contrary to the 'common chernozems', Miklaszewski distinguished the 'boggy chernozems' referred to by him as 'black earths' (czarne ziemie), developed from various glacial materials. The origin of these soils is closely related to former peatlands or shallow lakes because they were formed by mixing of post-bog organic matter (often a peat) with mineral subsoil after permanent and deep soil drainage. However, Miklaszewski noted the presence of transitional soils (i.e. developed from loess and having channels of burrowing animals (similar to chernozems), which are wet and contain 'acid' humus (similar to black earths). Miklaszewski (1930) also distinguished the 'podzolized chernozems' (i.e. soil with thick humus horizon, formed from loess, but leached from carbonates and having clearly higher clay content in the subsoil ('iluwjum') compared to topsoil).

Somewhat different classification of chernozems in Poland (in borders before the WWII) presented Mieczyński (1938), who distinguished 'degraded chernozems' (czarnoziemy zdegradowane), considered to be typical for the eastern Polish territories, 'northern chernozems' (czarnoziemy północne), 'poorly developed chernozems' (czarnoziemy niedokształcone), 'colluvial chernozems' (czarnoziemy deluwialne) and the moist 'Kuyavian chernozems' (czarnoziemy kujawskie). The latter may be correlated with the 'black earths' of Miklaszewski (1930); however, Mieczyński (1938) did not support the opinion on the post-boggy origin of these soils.
This simple distinction of chernozemic soils in Poland into the 'dry' common/degraded/podzolized chernozems and the 'moist' post-bog black earths has been maintained since the end of World War II (Przyrodniczo-genetyczna klasyfikacja gleb Polski 1956; Genetyczna klasyfikacja gleb Polski 1959) despite many pedologists reporting the presence of moist (secondary moistened) variants of chernozems and questioning the only one accepted process (a post-bog genesis) for all black earths' origination (Kowaliński 1952). Moreover, these genetically oriented classifications have omitted many specific variants of chernozemic soils, such as eroded chernozems (with thinned humus horizon) and colluvial chernozems (i.e. accumulated at the foot-slopes and local depressions) (Harasimiuk and Wicik 2010). As a result, the national system of arable soil evaluation, launched between 1956 and 1963, has applied more morphologically oriented criteria for naming and evaluating the chernozemic soils in Poland (Ministerstwo Rolnictwa 1963). The next edition of the Polish soil classification (Systematyka gleb Polski 1974) has significantly extended the divisions of chernozemic soils based on genetical criteria. Chernozems have been separated into steppe-forest and meadow-forest types to stress the presumed different conditions of their origin - more continental (drier) and more Atlantic (moister), in eastern and western Poland, respectively. Each of these two types has been further subdivided into two subtypes: common (non-degraded) and degraded, based on humus content in the topsoil layer and depth of carbonate accumulation in the soil profile. The loess-derived, moist, meadow-forest chernozems have been separated from the post-bog black earths developed from various parent materials. This classification has solved some old problems related to the genesis of chernozemic soils; however, it has also generated a number of new theoretical and practical issues. In particular, it was not clear how to classify the mosaic of chernozemic soils featured by substantial differentiation of their properties (e.g. of the moisture status) on a small area, where three different paths of chernozemic soil development seem impossible (steppe-forest in the highest, meadowforest in intermediate and post-bog in the lowest sites). Moreover, this new classification scheme did not explain regional differences in a classification of similar soils because the criteria to distinguish the meadow-forest chernozems and some black earths were still overlapping (Łabaz and Kabała 2014). As a consequence, the next, $4^{\text {th }}$ edition of the Polish Soil Classification (Systematyka Gleb Polski 1989) resigned from separating forest-steppe and meadowforest chernozems and returned to one type of 
chernozems with two subtypes (non-degraded and degraded), accompanied by black earths type (in the other soil order). Also, the concept of black earths has substantially changed: from a narrow post-bog origin to a much wider understanding of the semihydrogenic conditions of their formation that includes soils developed both in drained bogs, bottoms of drained former lakes and in moist meadows or meadowforest environments. Also, it should be stressed that the $4^{\text {th }}$ edition of the Polish Soil Classification (Systematyka Gleb Polski 1989) introduced the diagnostic horizons as a tool for soil type recognition, including the mollic horizon for chernozems and black earths. The $5^{\text {th }}$ edition of the Polish Soil Classification (Systematyka Gleb Polski 2011) retained the general rules for chernozems identification based on mollic horizons and secondary carbonates but abandoned the questioned division into non-degraded and degraded ones. Instead, the following five subtypes were distinguished: typical chernozems (having a mollic horizon 30-60 cm thick and secondary carbonates present in the profile), cumulative chernozems (having a mollic horizon $>60 \mathrm{~cm}$ thick), chernozems with cambic horizon, chernozems with argic horizon and chernozems with stagnic properties.

\section{CURRENT DEFINITION AND CLASSIFICATION OF CHERNOZEMS IN POLAND}

The $6^{\text {th }}$ edition of the Polish Soil Classification (Systematyka Gleb Polski 2019) has defined the chernozems as soils having a thick, nearly black and structural humus horizon (mollik) and secondary carbonates present within the soil profile (i.e. no deeper than $150 \mathrm{~cm}$ from the soil surface). Additional, indirect requirements for Chernozems result from the position of this soil group in the key to soil types within the chernozemic soil order (Kabała et al. 2019a). Chernozems cannot be developed from alluvial and colluvial (humus-rich) materials and thus typically occur beyond river valleys and other depressions or footslopes, occupied by chernozemic alluvial or colluvial soils, respectively (Strzemski 1961). Hence, the soils also developed from colluvial material from eroded Chernozems and located in foothills may not be classified as Chernozems if they have clearly recognisable diagnostic features of colluvial material. Chernozems may have poorly developed redoximorphic features but do not have the stagnic or gleyic properties in the upper and medium part of soil profile ( $<80 \mathrm{~cm}$ from the surface) that are diagnostic for the black earths. Moreover, Chernozems cannot be dominated by primary (lithogenic) carbo- nates from limestones and other carbonatic rocks that are crucial for chernozemic rendzinas (Kabała 2018; Miechówka and Drewnik 2018; Smreczak et al. 2018), situated before Chernozems in the key to soil types.

Taking into account the natural conditions of Poland, Chernozems are therefore the soils developed from (initially) carbonate-bearing loess, under the climate and vegetation that allowed accumulation of organic residues and extensive activity of burrowing animals, a process which resulted in the formation of thick and base saturated mollic horizon. No strict relation to a particular kind of vegetation was stated in the definition (key) because both the 'pure' steppe formations and the open-canopy forest-steppe or meadow-forest formations may support humus accumulation and intense zooturbation, at least by earthworms (Ehwald et al. 1999; Vysloužilová et al. 2014). The long-term coverage with close-canopy forests is rather excluded due to the fact that it would not only change the kind of biomass input and eliminate a significant part of animal activity, but would also support the leaching of carbonates out of the soil profile, common in Luvisols and Retisols neighbouring to the preserved chernozems (Kabała et al. 2019b; Ostaszewska et al. 2011). Chernozems may occur in flat landscape positions but more commonly are present on slightly inclined slopes, featured by good water drainage, which eliminates the high ground water table or surface water stagnation (and stronger expression of stagnic or gleyic properties). Such a moderately dry water regime does not limit the activity of earthworms and other burrowing animals. Limited intensity of erosion on gentle slopes does not disturb the topsoil layer and thus allows the recognition of chernozem, those definitions typically include the minimum thickness requirement for humus horizon (Dobrzański and Zbysław 1956; Licznar and Drozd 1985). In contrast, the soils on steep slopes, even if originally developed as chernozems under native vegetation and a beneficial climate, may be degraded to rendzinas (Strzemski et al. 1973; Borowiec 1967) or pararendzinas - Calcisols (Zádorová et al. 2013), when excessively eroded (Borowiec 1966).

The majority of chernozems identified in Poland are developed from thick loess. However, the definition of chernozems is not limited to loess, because some chernozems are reported to occur on a glacial till, which still contains some secondary carbonates (Borowiec 1962; Cieśla and Dąbkowska-Naskręt 1983; Cieśla et al. 1988), and other chernozems may have glaciofluvial or outwash sands, glacial tills or limestones underlying the topsoil developed from loess (Borowiec 1962; 1965; 1976; Olszewski et al. 1965). 
The latter materials may significantly influence the development of soil profile and soil properties, due to either enhanced water drainage or water retention. If the underlying material influences the soil properties too strongly, the soil may no longer fulfil the criteria for chernozem; this is particularly the case for underlying sands that support deep carbonate leaching (and soil shifting to decalcified grey soils) and impermeable loams/clays that contribute to the development of redoximorphic features and soil shifting to excessively moist black earths (Kabała et al. 2015; Dudek et al. 2019). Further, too shallow presence of limestone may mask the accumulations of secondary carbonates (if present at all) and leads to soil classification as chernozemic rendzina, which, in fact, may have a similar origin to typical chernozems (Miklaszewski 1930); however, having primary instead of secondary carbonates. The presence of carbonates in loess not only stabilizes the humus, thus supporting the formation of thick humus horizon, but also limits the weathering of minerals and transformation of chernozem (Drewnik et al. 2014).

Chernozems in Poland, even if steppe vegetation was confirmed to support their development in the Neolithic period (Chmielewski et al. 2014; MuellerBieniek and Nalepka 2010), differ of course from the 'typical' or even of the 'normal' chernozems of the central continental steppe zone in a humus content, which in Poland commonly varies in a range of 2 to 3\% (Borowiec 1962; 1965; 1968; Gąsior and Partyka 1999; Łabaz 2010; Olszewski et al. 1965; Turski 1985 ; 1986). The structure of soil mass in topsoil layers of the Polish chernozems rarely is granular, more often it is blocky subangular or even angular due to ploughing (Chudecki and Błaszczyk 1980; Domżał et al. 1991; Łabaz et al. 2018). Such a structure visibly differs from the granular or granular/coprolite structure of native, non-arable chernozems in the steppe zone (Khitrov and Loiko 2010). However, the arable 'normal' chernozems in the Woronezh and Belgorod regions also have a blocky angular or even cloddy structure in the topsoil layers after ploughing (Kabała 2016, personal observation; Khitrov et al. 2013), thus the structure cannot be a measure of differences between the zonal and extrazonal chernozems.

The recent, $6^{\text {th }}$ edition of the Polish Soil Classification (Systematyka gleb Polski 2019) has distinguished five subtypes of chernozems: (a) leached chernozems (PL: czarnoziemy wyługowane) that do not contain carbonates down to a depth of $100 \mathrm{~cm}$, (b) illuvial chernozems (PL: czarnoziemy iluwialne) that have clay translocation and argik horizons starting no deeper than $100 \mathrm{~cm}$ from the soil surface, (c) brown chernozems (PL: czarnoziemy zbrutniałe) that have a kambik horizon, (d) stagnogleyic chernozems (PL: czarnoziemy opadowo-glejowe) that have stagnic properties in a layer $>25 \mathrm{~cm}$ thick, starting $<80 \mathrm{~cm}$ from the soil surface and (e) typical chernozems (PL: czarnoziemy typowe) that have all required features of the type (coming from its position in a key to soil types) and do not have features required for the subtypes listed above. Thus, the 'typical chernozem' has a mollik horizon and accumulation of secondary carbonates starting $<100 \mathrm{~cm}$ from the surface, does not have kambik or argik horizons and does not have clearly developed stagnic (or gleyic) properties. Comparing to the previous Polish Soil Classifications (Systematyka gleb Polski 1974; 1989), the subtype 'typical' may be correlated with 'nondegraded', the 'stagnic' subtype with 'stagnogleyed', whereas the 'leached', 'brown' and 'illuvial' subtypes were merged previously into one subtype of 'degraded' chernozems. It should be noted that not all Polish chernozems, even the 'typical' ones, fulfil the criteria of Chernozems in the WRB classification (IUSS Working Group WRB 2015), which requires the presence of secondary carbonates at a depth no larger than $50 \mathrm{~cm}$ below the mollic horizon. In particular, the subtype of leached chernozems may refer to the Phaeozem group (Kabała et al. 2019a). On the other hand, it must be stressed that many Polish 'black earths' fulfil the criteria of (Gleyic/Stagnic) Chernozems in the WRB (Labaz et al. 2018). According to Soil Taxonomy (Soil Survey Staff 2014), all Polish chernozems meet the criteria of Mollisols and typically belong to Calciudolls or Hapludolls (Kabała et al. 2019a).

As stated above, the distinction between chernozems and black earths in SGP6 refers indirectly to soil genesis and directly to soil morphology and physicochemical properties. Both chernozems and black earths are featured by the presence of thick mollik horizon. Chernzoems must have a layer with secondary carbonate accumulation within the profile, while black earths - may have it. Whereas, chernozems do not have strong stagnic or gleyic properties, which, in turn, are required in black earths. Thus, the present definition of black earths includes soils of various origin, including polygenetic soils, featured by at least seasonal, excessive moisture of soil profile (either from high level of ground water or stagnating rain/melting waters), evidenced by stagnic or gleyic properties. This means, also the soils originated as steppe chernozems may be classified as black earths, if presently are situated in depressions, footslopes and other positions supporting water stagnation and development of reducing conditions in soil profile. 
This distinctions refers to different ecological functions of "dry" chernozems and "moist" black earths" and also different agricultural and forestry management required for these soil types (Strzemski et al. 1973; Turski 1985; Błońska and Lasota 2019).

\section{Distribution, land use and degradation of chernozems in Poland}

Soils traditionally identified in Poland as chernozems occur in isolated larger locations on the loess plateaus of southern Poland, near the towns Tomaszów Lubelski-Hrubieszów, Sandomierz, Przemyśl-Jarosław, Miechów-Proszowice, and Głubczyce (Borowiec 1965, 1968; Olszewski et al. 1965; Licznar 1976; Turski 1985; Czarnecki and Lewartowska-Urbańska 1987; Gąsior and Partyka 1999). Moreover, chernozems have been documented in mosaics with black earths, for example near Wrocław, Kłodzko, Inowrocław and Pyrzyce (Borowiec 1962; Cieśla et al. 1988; Drozd et al. 2007; Łabaz et al. 2018).

Due to properties beneficial to plant growth, nearly all chernozems in Poland are arable. Typical chernozems, developed from calcareous loess and having a thick humus horizon, have the highest agricultural evaluation belonging to class I or II of the national system. Leached, illuvial and brown chernozems have a beneficial texture; however, typically these chernozems are leached of carbonates to a larger depth and often have a thinner humus horizon. Thus, they typically belong to the II or IIIa evaluation class. Potentially, some limitations to plant growth may occur in stagnogleyic chernozems, and therefore they typically belong to IIIa and IIIb evaluation classes. Chernozems of various subtypes (excluding the stagnogleyed ones) may have a lower evaluation class (IIIa or IIIb, respectively to their properties) if they are located on slopes suffering from erosion. Nevertheless, nearly all chernozems belong to the 1 st and 2nd agricultural land suitability category (complex) (i.e. lands dedicated to growing the most demanding crops, such as wheat, sugar beet, corn and rape) (Strzemski et al. 1973).

Quality of chernozems and their degradation have been the subject of numerous studies. In particular, research regarding the composition and functions of humus are frequently found in the literature. The characterization of the amounts and ratios of particular humic compounds demonstrated the similarity of Polish chernozems to Ukrainian and Russian ones but also the similarity (sometimes interpreted as similar soil origin) of chernozems and other soil types, such as black earths or smonitza (Wilk and Nowak 1977; Turski 1986; Drozd et al. 2007; Łabaz
2010). However, the composition of humus may significantly differentiate in chernozems existing at various locations, under various vegetation and cultivation practices (Kuźnicki and Skłodowski 1968; Turski and Chmielewska 1986). The quality of humus has been found to negatively change under long-term cultivation of cereals in monoculture (Turski and Flis-Bujak 1980). Wilk and Nowak (1977) reported that organic fertilization of chernozems and other soils may not enhance soil fertility and crop yields directly but is crucial for stabilizing the content and composition of humus, and thus, influences the soil productivity indirectly. Also, erosion may substantially contribute to the quality of humus in chernozems, both by selective removal/accumulation of humus complexed with fine earth particles and transformation of humic compounds after burial with colluvial material (Licznar and Drozd 1985; Licznar et al. 1993).

Chernozems in Poland generally have a high content of nutrients (Borowiec 1965; 1971; Olszewski et al.1965; Licznar 1976; Bieganowski et al. 2013; Łabaz et al. 2018) and low concentrations of chemical contaminants, including heavy metals (Skłodowski and Sapek 1977; Czarnowska 1989; Gąsior and Partyka 1999; Jeleńska et al. 2008; Domańska 2009). However, the content of cadmium and lead in topsoil layers is 3 to 5 times higher compared to buried (Neolithic) chernozems (Labaz et al. 2019). This observation may indicate a general (large-scale) contamination of the environment with these metals since the beginning of the industrial epoch (lead) or modern agriculture (cadmium). Local contamination of chernozems due to industrial emissions, for example with salts, is rarely reported (Brogowski et al. 1975).

The common source of threats for chernozems' quality and even their existence is generated by intense agricultural land use (Witkowska-Walczak et al. 1999). Domżał and al. (1991) and Słowińska-Jurkiewicz et al. (2013) reported that the transformation of soil structure in the topsoil layer is affected by tractor wheels or long-term fertilization. Intense cultivation, including the regular ploughing and mineral fertilization, leads to a decrease of humus content in topsoil layer and transformation to 'grey soils' (Borkowski 1964; Licznar 1976; Kowaliński et al. 1987). The most serious problem for chernozems related to agriculture is the sheet erosion that may accelerate chemical denudation and nutrient loss (Jadczyszyn et al. 2014) and subsequent thinning of the humus layer by physical losses of surface, humus-rich material (Licznar and Drozd 1985; Licznar et al. 1993; Górka-Kostrubiec et al. 2016; Gasior et al. 2017). Erosion of chernozems in Central Europe began with early agricultural practices, which destroyed the natural vegetation 
cover and opened soil surface to water action but has critically accelerated with the introduction of ploughing (Kołodyńska-Gawrysiak et al. 2017; Zadorova et al. 2013). Long-term erosion may lead to the disappearance of chernozem by its transformation to pararędzina/Calcisol (Dobrzański and Zbysław 1956). Therefore, conservation practices that will protect chernozems both against erosion and humus loss are urgently required (Borowiec 2002) because the true area of chernozems has clearly decreased compared to their surface, evidenced in soil-agricultural maps prepared in the1960s (Kabała and Labaz 2019, data unpublished).

\section{ACKNOWLEDGEMENT}

I would like to thank all the members of the Soil Science Society of Poland, in particular the members of the Commission for the Soil Genesis, Classification and Cartography, who got involved in the implementation of the program "Soil of the Year", including the preparation of a special issue of Soil Science Annual focused on Chernozems and related soils.

\section{REFERENCES}

Altermann M., Rinklebe J., Merbach I., Körschens M., Langer U., Hofmann B., 2005. Chernozem soil of the year 2005. Journal of Plant Nutrition and Soil Science 168(6): 725-740.

Bieganowski A., Witkowska-Walczak B., Gliński J., Sokołowska Z., Sławiński C., Brzezińska M., Włodarczyk T., 2013. Database of Polish arable mineral soils: a review. International Agrophysics 27(3): 335-350.

Borkowski J., 1964. Czarne i szare ziemie wytworzone z utworów pyłowych i pylastych na obszarze Śląska. Roczniki Gleboznawcze - Soil Science Annual 14(1): 61-78.

Borowiec S., 1962. O występowaniu reliktowych czarnoziemów na terenie województwa szczecińskiego. Przegląd Geograficzny 34(4): 739-747.

Borowiec J., 1965. Czarnoziemy Wyżyny Lubelskiej. Cz. I. Warunki występowania i ogólna charakterystyka gleb. Annales UMCS, seria B, 19: 1-19.

Borowiec J., 1966. Wpływ wylesienia i użytkowania rolniczego na morfologię i właściwości czarnoziemu w terenie urzeźbionym. Annales UMCS, sec. E, 21: 144 pp.

Borowiec J., 1967. Czarnoziemy Wyżyny Lubelskiej. Cz. II. Problemy genezy, ewolucji i typologii gleb. Annales UMCS, seria $\mathrm{B}, 22$ : $39-58$.

Borowiec J., 1968. The problem of typology and development trends of chernozems occurring in Poland. Roczniki Gleboznawcze - Soil Science Annual 19: 253-260.

Borowiec J., 1971. Formy fosforu, ich udział i przemiany w glebie na przykładzie polskich czarnoziemów. Annals UMCS, sec. E, 26(15): 321-354.

Borowiec J., 1976. Czarnoziemy polskie w świetle badan Profesora Sławomira Miklaszewskiego. Roczniki Gleboznawcze - Soil Science Annual 27(2): 159-165.

Borowiec J., 2002. Znaczenie lasu w ochronie gleby przed erozją na przykładzie ewolucji polskich czarnoziemów. Zeszyty Problemowe Postępów Nauk Rolniczych 487: 233-242.
Brogowski Z., Czerwiński Z., Tuszyński M., 1975. Wpływ emisji $\mathrm{NaCl}$ na gleby i roślinność okolicy żupy solnej w Wieliczce. Roczniki Gleboznawcze - Soil Science Annual, 26(3): 259-275.

Chmielewski T.J., Furmanek M., Patay R., Sady A., 2014. Needle grass (Stipa sp.) in the Neolitic and Eneolithic periods in Central Europe. Contribution to the discussion on the phenomenon. Arheovest, JatePress Kiado, Szeged, Hungary: 109-133.

Chudecki Z., Błaszczyk H., 1980. Strukturotwórcza funkcja próchnicy w pyrzyckich uprawnych czarnoziemach i czarnych ziemiach. Roczniki Gleboznawcze - Soil Science Annual 31(3-4): 85-92.

Cieśla W., Dąbkowska-Naskręt H., 1983. Skład chemiczny frakcji ilastej gleb wytwarzanych z glin zwałowych moren dennych niziny wielkopolskiej. Roczniki Gleboznawcze - Soil Science Annual 34(3): 37-54.

Cieśla W., Dąbkowska-Naskęt H., Dymińska M., Jaworska H., 1988. Uziarnienie frakcji iłu koloidalnego w wybranych glebach Wysoczyzny Kujawskiej. Roczniki Gleboznawcze Soil Science Annual 39(3): 213-216.

Czarnowska K., 1989. Zawartość niektórych metali ciężkich w glebach wytworzonych z różnych utworów pyłowych. Roczniki Gleboznawcze - Soil Science Annual 37(1): 153-163.

Czarnecki R., Lewartowska-Urbańska M., 1987. Wymoki okolic Sandomierza. Przegląd Geograficzny 59(3): 385-399.

Czerny P., Sachsse H.F., 1965. Bodenkundliche Untersuchungen an einer fossilen und einer rezenten Schwarzerde. Archives of Agronomy and Soil Science 9(10): 867-881.

Dobrzański B., Zbysław B., 1956. Wpływ erozji na ewolucję czarnoziemów. Roczniki Nauk Rolniczych 7: 122 pp.

Dokuchaev V.V., 1883. Russkij Chernozem. Sankt Petersburg: $376 \mathrm{pp}$.

Domańska J., 2009. Soluble forms of zinc in profiles of selected types of arable soils. Journal of Elementology 14: 55-62.

Domżał H., Gliński J., Lipiec J., 1991. Soil compaction research in Poland. Soil and Tillage Research 19(2-3): 99-109.

Drewnik M., Skiba M., Szymański W., Żyła M., 2014. Mineral composition vs. soil forming processes in loess soils - a case study from Kraków (Southern Poland). Catena 119: 166-173.

Drozd J., Piątek J., Łabaz B., 2007. Właściwości gleb czarnoziemnych występujących w rejonie Kłodzka. Zeszyty Problemowe Postępów Nauk Rolniczych 520, 2: 24-36.

Dudek M., Waroszewski J., Kabała C., Łabaz B., 2019. Vertisols and black earths developed from Neogene clays and accompanying materials in the Niemcza-Strzelin Hills (SW Poland) - morphology, properties and classification. Soil Science Annual 70(2): 158-169.

Eckmeier E., Gerlach R., Gehrt E., Schmidt M.W.I., 2007. Pedogenesis of Chernozems in central Europe - A review. Geoderma 139: 288-299.

Ehwald E., Jäger K.D., Lange E., 1999. Das Problem Wald Offenland im zirkumherzynen Trockengebiet von der neolithischen Besiedlung sowie die Entstehung der zirkumherzynen Schwarzerden. Hamburger Werkstattreihe zur Archäologie 4: 12-34.

Gąsior J., Partyka A., 1999. Czarnoziemy południowo-wschodniej Polski i ich degradacja. Zeszyty Problemowe Postępów Nauk Rolniczych 467: 234-232.

Gąsior J., Właśniewski S., Hamor A., Bartman M., 2017. Procesy glebowe na północnym stoku Cergowej jako wskaźniki geomorfologicznych procesów stokowych w Beskidzie Niskim. Acta Carpathica 13. 
Genetyczna klasyfikacja gleb Polski, 1959. Roczniki Gleboznawcze - Soil Science Annual 7(2): 1-103.

Górka-Kostrubiec B., Teisseyre-Jeleńska M., Dytłow S.K., 2016. Magnetic properties as indicators of Chernozem soil development. Catena 138: 91-102.

Hajdukiewicz H., 2010. Późnovistuliański i holoceński rozwój dolin dorzecza Małoszówki. Prace Geograficzne/Instytut Geografii i Gospodarki Przestrzennej Uniwersytetu Jagiellońskiego 123: 63-81.

Harasimiuk A., Wicik B. 2010. Substancje humusowe gleb w świetle wyników ekstrakcji gorącą wodą (gleba płowa, szara gleba leśna, czarnoziem). Roczniki Gleboznawcze - Soil Science Annual 61(1): 38-44.

IUSS Working Group WRB, 2015. World References Base for Soil Resources 2014, Update 2015, World Soil Resources Reports, 106, FAO, Rome: 192 pp.

Jacomet S., Ebersbach R., Akeret Ö., Antolin F., Baum T., Bogaard A., Gross E., 2016. On-site data cast doubts on the hypothesis of shifting cultivation in the late Neolithic (c. 4300-2400 cal. BC): Landscape management as an alternative paradigm. The Holocene 26(11): 1858-1874.

Jadczyszyn J., Mroczkowski W., Gosek S., 2014. Erozyjne straty fosforu w doświadczeniu modelowym. Inżynieria i Ochrona Środowiska 17(1): 89-103.

Jeleńska M., Hasso-Agopsowicz A., Kądziałko-Hofmokl M., Sukhorada A., Bondar K., Matviishina Z., 2008. Magnetic iron oxides occurring in chernozem soil from Ukraine and Poland as indicators of pedogenic processes. Studia Geophysica et Geodaetica 52(2): 255-270.

Kabała C., 2018. Rendzina (rędzina) - Soil of the Year 2018 in Poland. Introduction to origin, classification and land use of rendzinas. Soil Science Annual 69(2): 63-74.

Kabała C., Charzyński P., Chodorowski J., Drewnik M., Glina B., Greinert A., Hulisz P., Jankowski M., Jonczak J., Łabaz B., Łachacz A., Marzec M., Mendyk Ł., Musiał P., Musielok Ł., Smreczak B., Sowiński P., Świtoniak M., Uzarowicz Ł., Waroszewski J., 2019a. Polish Soil Classification, 6th edition - principles, classification scheme and correlations. Soil Science Annual 70(2): 71-97.

Kabała C., Płonka T., Przekora A., 2015. Vertic properties and gilgai-related subsurface features in soils of south-western Poland. Catena 128: 95-107.

Kabała C., Przybył A., Krupski M., Łabaz B., Waroszewski J., $2019 \mathrm{~b}$. Origin, age and transformation of Chernozems in northern Central Europe - New data from Neolithic earthen barrows in SW Poland. Catena 180: 83-102.

Khitrov N.B., Gerasimova M.I., Bronnikova M., Zazovskaya E. P., 2013. Chernozem of Kursk Biosphere Station of IG RAS [In:] Guide for Field Excursions XIIth International Symposium and Field Seminar on Paleopdology. Moscow: 42-50.

Khitrov N., Smirnova M., Lozbenev N., Levchenko E., Gribov V., Kozlov D., Rukhovich D., Kalinina N., Koroleva P., 2019. Soil cover patterns in the forest stepppe and steppe zones of the East European Plain. Soil Science Annual 70(2): 198210.

Kõlli R., Tamm I., 2015. Soil on limestone - year 2015 soil of Estonia. Agraarteadus 26(2): 51-61.

Kołodyńska-Gawrysiak R., Chodorowski J., Mroczek P., Plak A., Zgłobicki W., Kiebała A., Standzikowski K., 2017. The impact of natural and anthropogenic processes on the evolution of closed depressions in loess areas. A multi-proxy case study from Nałęczów Plateau, Eastern Poland. Catena 149: $1-18$.
Kowaliński S., 1952. Czarne ziemie Wrocławskie. Roczniki Gleboznawcze - Soil Science Annual 2: 59-91.

Kowaliński S., Licznar M., Drozd J., Licznar S.E., 1987. Mikromorfologiczna interpretacja procesów fizyko chemicznych w glebach czarnoziemnych różnych rejonów Polski. Roczniki Gleboznawcze - Soil Science Annual 38(2): 77-100.

Kuźnicki F., Skłodowski P., 1968. Przemiany substancji organicznej w niektórych typach gleb Polski. Roczniki Gleboznawcze - Soil Science Annual 19(1): 3-25.

Lasota J., Błońska E., Łyszczarz S., Sadowy A., 2019. Forest habitats and forest types on chernozems in south-eastern Poland, Soil Science Annual 70(33): 234-243.

Licznar M., 1976. Właściwości i geneza niektórych gleb czarnoziemnych Płaskowyżu Głubczyckiego. Roczniki Gleboznawcze - Soil Science Annual 27(4): 107-148.

Licznar M., Drozd J., 1985. Wpływ erozji na właściwości związków próchnicznych w niektórych jednostkach systematycznych gleb. Roczniki Gleboznawcze - Soil Science Annual, 36(3): 189-199.

Licznar M., Drozd J., Licznar S.E., 1993. Skład ilościowy i jakościowy związków próchnicznych gleb deluwialnych Płaskowyżu Głubczyckiego. Zeszyty Problemowe Postępów Nauk Rolniczych 411: 139-148.

Liu X., Lee Burras C., Kravchenko Y. S., Duran A., Huffman T., Morras H., Yuan X., 2012. Overview of Mollisols in the world: distribution, land use and management. Canadian Journal of Soil Science 92(3): 383-402.

Łabaz B., 2010. Właściwości kwasów huminowych gleb czarnoziemnych występujących w rejonie Kłodzka. Woda-Środowisko-Obszary Wiejskie 10: 153-164.

Łabaz B., Kabała C., 2014. Geneza, właściwości i klasyfikacja czarnych ziem w Polsce. Soil Science Annual 65(2): 80-90.

Łabaz B., Musztyfaga E., Waroszewski J., Bogacz A., Jezierski P., Kabala C., 2018. Landscape-related transformation and differentiation of Chernozems - Catenary approach in the Silesian Lowland, SW Poland. Catena 161: 63-76.

Łabaz B., Kabala C., Waroszewski J., 2019. Ambient geochemical baselines for trace elements in Chernozems - approximation of geochemical soil transformation in an agricultural area. Environmental Monitoring and Assessment 191: 19.

Maruszczak H., 1998. Wpływ gospodarki neolitycznej na rozwój tzw. czarnoziemów hrubieszowsko-tomaszowskich. Przegląd Geograficzny 70(3-4): 333-342.

Miechówka A., Drewnik M., 2018. Rendzina soils in the Tatra Mountains, central Europe: a review. Soil Science Annual 69(2): 88-100.

Mieczyński T., 1938. Gleboznawstwo terenowe. Państwowy Instytut Naukowy Gospodarstwa Wiejskiego, Puławy: 337 pp.

Miedema R., Koulechova I. N., Gerasimova M. I., 1999. Soil formation in Greyzems in Moscow district: micromorphology, chemistry, clay mineralogy and particle size distribution. Catena 34: 315-347.

Miklaszewski S., 1906. Gleby ziem polskich ze szczególnym uwzględnieniem Królestwa Polskiego. Przegląd Rolniczy, kwartał III i IV.

Miklaszewski S., 1930. Gleby Polski. Komisja Wydawnicza TBPS Politechniki Warszawskiej, Warszawa: 640 pp.

Ministerstwo Rolnictwa, 1963. Komentarz do tabeli klas gruntów. Warszawa: 464 pp.

Mueller-Bieniek A., Nalepka D., 2010. Do findings of feather grass (Stipa sp.) from the Neolithic of Southern Kujawy area indicate the existence of xerothermic grasslands during the climatic optimum? [In:] Ciepłolubne murawy w Polsce - stan zachowania i perspektywy ochrony (Ratyńska H., Waldon B., 
Editors). Wydawnictwo Uniwersytetu Kazimierza Wielkiego, Bydgoszcz: 235-248.

Olszewski Z., Barański E., Skłodowski P., 1965. Czarnoziemy proszowskie. Roczniki Nauk Rolniczych 90: 61-111.

Ostaszewska K., Heinrich J., Schmidt R., Krüger A., 2011. Użytkowanie ziemi jako czynnik krajobrazotwórczy na obszarach lessowych. Prace i Studia Geograficzne 46: 63-76.

Pokorný P., Chytrý M., Juřičková L., Sádlo J., Novák J., Ložek V., 2015. Mid-Holocene bottleneck for central European dry grasslands: Did steppe survive the forest optimum in northern Bohemia, Czech Republic? The Holocene 25(4): 716-726.

Ponomarenko D., Ponomarenko E., 2019. Describing krotovinas: A contribution to methodology and interpretation. Quaternary International 502: 238-245.

Pozniak S.P., Havrysh N.S., 2019. Soils in the memory of world nations. Polish Journal of Soil Science 52(1): 1-13.

Przyrodniczo-genetyczna klasyfikacja gleb Polski, 1956. Roczniki Nauk Rolniczych 74, D: 1-96.

Skłodowski P., Sapek A., 1977. Rozmieszczenie Fe, Zn, Mn, $\mathrm{Cu}, \mathrm{Co}, \mathrm{Ni}, \mathrm{Pb}$ i Cd w profilach czarnoziemów leśno-stepowych. Roczniki Gleboznawcze - Soil Science Annual 28(1): $71-84$.

Słowińska-Jurkiewicz A., Bryk M., Medvedev V. V., 2013. Longterm organic fertilization effect on Chernozem structure. International Agrophysics 27(1): 81-87.

Smreczak B., Jadczyszyn J., Kabała C., 2018. Agricultural suitability of rendzinas in Poland. Soil Science Annual 69(2): 142-151.

Soil Survey Staff, 2014. Keys to Soil Taxonomy, 12th ed. USDA-Natural Resources Conservation Service, Washington, DC: 633 pp.

Strzemski M., 1961. Przemiany środowiska geograficznego Polski, jako tła przyrodniczego rozwoju rolnictwa na ziemiach polskich: od połowy trzeciego tysiąclecia p.n.e. do naszych czasów. Kwartalnik Historii Kultury Materialnej 9(3): 331-357.

Strzemski M., 1971. Myśli przewodnie systematyki gleb. Państwowe Wydawnictwo Rolnicze i Leśne, Warszawa: 425 pp.

Strzemski M., 1980. Historia gleboznawstwa polskiego. Państwowe Wydawnictwo Rolnicze i Leśne, Warszawa: 224 pp.

Strzemski M., Siuta J., Witek T., 1973. Przydatność rolnicza gleb Polski, Państwowe Wydawnictwo Rolnicze i Leśne, Warszawa: $325 \mathrm{pp}$.

Suchodoletz H., Tinapp C., Lauer T., Glaser B., Stäuble H., Kühn P., Zielhofer C., 2017. Distribution of Chernozems and
Phaeozems in Central Germany during the Neolithic period. Quaternary International 511: 166-184.

Systematyka gleb Polski, 1974. Roczniki Gleboznawcze - Soil Science Annual 25(1): 1-148.

Systematyka gleb Polski, 1989. Roczniki Gleboznawcze - Soil Science Annual 40(3/4): 1-150.

Systematyka gleb Polski, 2011. Roczniki Gleboznawcze - Soil Science Annual 62(3): 1-193.

Systematyka gleb Polski, 2019. Wydawnictwo Uniwersytetu Przyrodniczego we Wrocławiu, Polskie Towarzystwo Gleboznawcze, Wrocław-Warszawa: 292 pp.

Turski R., 1985. Geneza i właściwości czarnoziemów Wyżyny Zachodniowołyńskiej i Lubelskiej. Roczniki Nauk Rolniczych, seria D, 202: 156 pp.

Turski R., 1986. Związki próchniczne gleb polskich. Roczniki Gleboznawcze - Soil Science Annual 37(2-3): 75-89.

Turski R., Chmielewska B., 1986. Kwasy huminowe gleb czarnoziemnych. Roczniki Gleboznawcze - Soil Science Annual 37(2-3): 75-89.

Turski R., Flis-Bujak M., 1980. Przemiany związków próchniczych w podobnie użytkowanych glebach różnego pochodzenia. Roczniki Gleboznawcze - Soil Science Annual 31(3-4): 299-307.

Vysloužilová B., Ertlen D., Schwartz D., Šefrna L., 2016. Chernozem. From concept to classification: a review. AUC Geographica 51: 85-95.

Vysloužilová B., Ertlen D., Šefrna L., Novák T., Virágh K., Rué M., Campaner A., Dreslerová D., Schwartz D., 2014. Investigation of vegetation history of buried chernozem soil using near-infrared spetroscopy (NIRS). Quaternary International 365: 203-211.

Wilk K., Nowak W., 1977. Skład frakcyjny związków próchnicznych niektórych typów gleb uprawnych. Roczniki Gleboznawcze - Soil Science Annual 23(2): 33-47.

Witkowska-Walczak B., Walczak R., Sławiński C., 1999. Charakterystyki potencjału wody glebowej - wilgotność czarnoziemów Polski. Acta Agrophysica 22: 265-273.

Zádorová T., Penížek V., Šefrna L., Drábek O., Mihaljevič M., Volf Š., Chuman T., 2013. Identification of Neolithic to Modern erosion-sedimentation phases using geochemical approach in a loess covered sub-catchment of South Moravia, Czech Republic. Geoderma 195: 56-69.

Received: July 21, 2019

Accepted: August 14, 2019

Associated editor: A. Lachacz

\section{Czarnoziem - gleba roku 2019 w Polsce. Geneza, klasyfikacja i użytkowanie czarnoziemów w Polsce}

Streszczenie: Decyzją Polskiego Towarzystwa Gleboznawczego, czarnoziem został ogłoszony glebą roku 2019. Choć czarnoziemy pokrywają mniej niż $2 \%$ powierzchni Polski, mają duże znaczenie dla rolnictwa dzięki ich wysokiej produktywności. Odgrywają też specjalną rolę w badaniach nad zrozumieniem genezy gleb oraz funkcjonowania gleb w środowisku przyrodniczym. Czarnoziemy są szczególnie użyteczne w rekonstrukcjach paleośrodowiskowych, na przykład w odtwarzaniu historii rolnictwa neolitycznego i rosnącego wpływu człowieka na gleby i krajobraz. W niniejszym artykule wstępnym (a) zaprezentowano specyficzną współczesną definicję czarnoziemów w Polsce, uwzględniającą osobną klasyfikację czarnych ziem i gleb deluwialnych czarnoziemnych, które w innych klasyfikacjąch moge również być zaliczane do czarnoziemów, (b) dokonano przeglądu historii klasyfikacji czarnoziemów w Polsce oraz ich współczesnej pozycji taksonomicznej na tle międzynarodowych systemów (WRB i Soil Taxonomy), (c) omówiono występowanie i wartość bonitacyjną czarnoziemów w Polsce, a także zagrożenia dla jakości $\mathrm{i}$ istnienia czarnoziemów wynikające z intensywnego użytkowania rolniczego.

Stowa kluczowe: czarnoziemy, czarne ziemie, gleby szare, geneza gleb, systematyka gleb, funkcje gleb 